Manehester studies in Religion. Culture and Gender

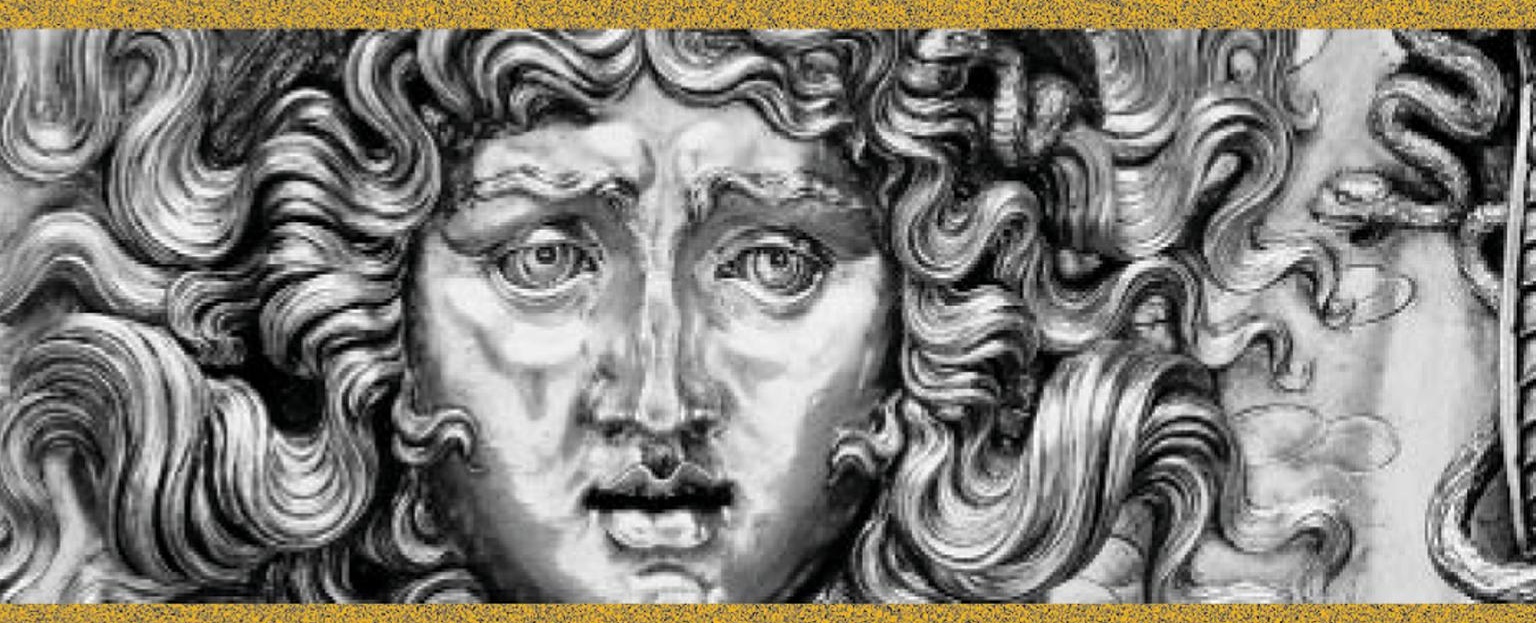

\title{
Literature, theology and feminism
}

Hecther Walton 


\section{Literature, theology and feminism}

\section{MANCHESTER 1824}

Manchester University Press 
edited by Grace M. Jantzen

Already published

\section{Religion and culture}

Michel Foucault

selected and edited by Jeremy R. Carrette

\section{Representations of the post/human}

Monsters, aliens and others in popular culture

Elaine L. Graham

\section{Becoming divine}

Towards a feminist philosophy of religion

Grace M. Jantzen

\section{Divine Love}

Luce Irigaray, women, gender, and religion

by Morny Joy 


\section{Literature, theology and feminism}

Heather Walton

Manchester University Press

Manchester 


\section{Copyright (C) Heather Walton 2007}

The right of Heather Walton to be identified as the author of this work has been asserted by her in accordance with the Copyright, Designs and Patents Act 1988.

Published by Manchester University Press

Altrincham Street, Manchester M1 7JA, UK

www.manchesteruniversitypress.co.uk

British Library Cataloguing-in-Publication Data

A catalogue record for this book is available from the British Library

ISBN 9780719060908 hardback

First published 2007

$16151413121110090807 \quad 10987654321$

Typeset in Joanna with Frutiger display

by Koinonia, Manchester 